\title{
PELAS VEREDAS DE UMA OBTUSA BIBLIOTECA: UMA LEITURA DA INTERDISCURSIVIDADE DA ESCRITURA DE MACHADO DE ASSIS
}

\author{
Luciana Antonini Schoeps \\ Universidade de São Paulo / CAPES \\ São Paulo (SP), Brasil
}

\begin{abstract}
Resumo: Este artigo propõe apresentar algumas questões concernentes ao estudo do aspecto interdiscursivo da escritura machadiana, compreendido aqui como a relação com discursos jáescritos empreendida a partir do espaço da biblioteca. Partiremos de uma sucinta apresentação do percurso histórico da biblioteca pessoal de Machado, a fim de tecer algumas considerações sobre a aproximação entre escrita e leitura, para, em seguida, analisarmos o que chamamos de biblioteca ficcional, isto é, a maneira pela qual a escritura ficcionaliza e relaciona-se com os discursos já-escritos. Nesse movimento, percebe-se que essa interdiscursividade acaba por problematizar as condições de enunciabilidade e de legibilidade da própria obra literária, apontando para o caráter preponderantemente crítico da ficção de Machado de Assis.
\end{abstract}

Palavras-chave: interdiscursividade; escritura; bibliotecas particulares; enunciabilidade; legibilidade.

\section{Through the paths of an obtuse library: a reading of the interdiscursivity within Machado de Assis's writing}

\begin{abstract}
This article aims at presenting some questions regarding the study of the interdiscursivity in Machado's writing, taken here as the relationship with already written discourses, constructed through the space of the library. Having as a starting point a concise exposition of Machado's private library historical course, in order to consider the association between writing and reading, we intend to analyze afterwards what we identify as a fictional library, that is, the manner in which writing fictionalizes these already written discourses and establishes a relationship with them. Thus, we notice that the interdiscursivity brings questions to the enunciability and the legibility of the literary work, revealing the prevailing critical aspect of the Machado de Assis' fiction.
\end{abstract}

Keywords: interdiscursivity; writing; private libraries; enunciability; legibility. 
Ao falarmos em estudos literários que evocam a biblioteca de um escritor, remetemos diretamente o leitor destas linhas à imagem de um espaço ocupado por estantes repletas de livros antigos, rijamente encadernados, com aparência desgastada pela passagem do tempo, pela poeira e pelos vermes.

Jamais pensamos em uma coleção de livros, antigos e empoeirados sim, mas cobertos por uma capinha de papel cartonado amarelo e protegidos por trás das portas de vidro de uma estante, todos catalogados e organizados por "domínios linguísticos", sem a menor lembrança de sua original distribuição nas estantes do autor, nas quais a intensa frequentação os fazia viver e conviver juntos, lado a lado, tomo a tomo, ao longo da leitura-escrita cotidiana. Pois foi assim que encontramos a biblioteca de Machado de Assis, numa alta estante do salão principal da Biblioteca Lúcio de Mendonça, na Academia Brasileira de Letras (ABL).

Acervo atualmente organizado segundo a catalogação pioneira de Jean-Michel Massa, ${ }^{1}$ essa biblioteca sofreu várias mutações em sua composição, sucedendo-se perdas e, talvez, enxertos ao longo de seu percurso histórico, desde o período imediatamente posterior à morte do autor até a integração definitiva pela $\mathrm{ABL}$, passando pelo período de permanência com os herdeiros. Segundo Massa, em sua incursão pelo acervo livresco de Machado, encetada em 1960 na casa dos herdeiros, estes teriam afirmado que um lote de duzentos livros havia sido doado logo após a morte do autor e outro, constituído por vários volumes em brochura, deteriorou-se em uma garagem durante a ausência da família, quando da Segunda Guerra Mundial.

Conforme o testamento deixado por Machado de Assis, sua biblioteca e todos os seus bens e objetos pessoais, excetuando-se apenas a propriedade das obras literárias, deixada para o editor Garnier, foram legados a Laura Leitão de Carvalho, filha da sobrinha de sua esposa Carolina e afilhada do casal Machado de Assis. ${ }^{2}$ Contudo, segundo descobriu a pesquisadora Glória Vianna em sua pesquisa nas atas das sessões

\footnotetext{
${ }^{1}$ Catalogação publicada em 1961 (Revista do Livro, no 21 e 22) e em 2001 (MASSA, Jean-Michel. A biblioteca de Machado de Assis. In: JOBIM, José Luís [Org.]. A biblioteca de Machado de Assis. Rio de Janeiro: ABL; Topbooks, 2001. p. 21-90).

2 "[N]omeio herdeira única a menina Laura, filha de minha sobrinha e comadre Sara Braga da Costa e de seu esposo e meu compadre Major Bonifácio Gomes da Costa. // A propriedade das minhas obras literárias pertence ao meu editor Garnier". (ASSIS, Testamento, apud. VIANNA, Revendo a biblioteca de Machado de Assis. In: JOBIM, José Luís [Org.]. A biblioteca de Machado de Assis. Rio de Janeiro: ABL; Topbooks, 2001. p. 113).
} 
acadêmicas da ABL, Machado havia declarado verbalmente na antevéspera de sua morte a transmissão de parte de seu espólio para a Academia, em meio ao qual estava a sua biblioteca pessoal. Após uma negociação amigável entre a ABL e a família da herdeira, com o objetivo de reaver para a primeira o legado machadiano, procedeu-se à transmissão para a Academia, em 30 de novembro de 1908, de "papéis manuscritos, originais, correspondências, retratos com dedicatórias, pequenos quadros oferecidos por amigos a Machado, a secretária e a cadeira que haviam sido usadas pelo escritor desde 1874, além de várias obras com dedicatórias", ${ }^{3}$ cujos títulos não foram listados na ata da sessão que anunciava o acordo com os herdeiros. Esse episódio da biblioteca machadiana explicaria, assim, a referida doação de parte dos livros do escritor logo após a sua morte.

Depois de um longo período de aparente esquecimento, o assunto voltou a ser discutido somente nas comemorações do cinquentenário da morte do autor, em 1958. No entanto, a biblioteca de Machado só foi definitivamente transferida para a ABL por volta de 1964, sem que se tenha registrado nas atas das sessões acadêmicas nem a data exata, nem a lista dos livros transferidos, ${ }^{4}$ não se podendo verificar se a totalidade dos livros catalogados por Massa em 1960 chegou intacta à Academia alguns anos depois.

Uma nova catalogação só seria efetuada na década de 1990, pela já citada pesquisadora Glória Vianna. Segundo sua recontabilização do acervo e a partir de uma atualização da lista de Massa, não foram localizados 77 exemplares, o que apontava para uma nova perda no acervo da biblioteca de Machado. A pesquisadora também revelou outra importante mudança em sua constituição, ao encontrar, em meio aos demais acervos da Academia, 15 exemplares, todos dedicados a Machado de Assis, apontando para o fato de que esses livros poderiam fazer parte do lote de livros doados à Academia e incorporados ao acervo geral da ABL logo após a sua morte.

Além disso, Vianna contabilizou no acervo total dos livros pertencentes a Machado a existência de exemplares carimbados com o nome do marido de Laura, o Marechal E. Leitão de Carvalho, o que apontaria para um possível enxerto de livros na

\footnotetext{
${ }^{3}$ VIANNA, Glória. Revendo a biblioteca de Machado de Assis. In: JOBIM, José Luís (Org.). A biblioteca de Machado de Assis. Rio de Janeiro: ABL; Topbooks, 2001. p. 114. Grifos do autor.

${ }^{4}$ Segundo Vianna, a única menção nas atas à biblioteca machadiana já transferida é de 30 de dezembro de 1964 (VIANNA, Glória. Revendo a biblioteca de Machado de Assis, cit., p. 118.).
} 
biblioteca original do escritor. A real origem de tais exemplares, no entanto, é dúbia, restando-nos apenas hipóteses, já que, apesar de conter o nome do esposo da herdeira, alguns tomos encontrados possuíam também dedicatórias a Machado:

\begin{abstract}
Ademais, o fato de verificarmos que 89 volumes da Biblioteca de Machado haviam sido carimbados com o nome de E. Leitão de Carvalho, esposo da herdeira do escritor, gerou muita inquietação, pois tal observação poderia levar-nos a supor que a biblioteca fora enxertada com os livros do Sr. Leitão de Carvalho... Mas, curiosamente, dentre os 89 volumes nos quais encontramos o referido carimbo, cinco estavam dedicados a Machado de Assis. ${ }^{5}$
\end{abstract}

Desde então, segundo nos informou Luiz Antônio de Souza, o bibliotecário responsável pela Biblioteca Acadêmica Lúcio de Mendonça, em nossa visita à ABL em 2011, o sistema de catalogação da biblioteca foi informatizado, e durante esse processo foram encontrados, em meio ao resto do acervo da ABL, mais volumes contendo dedicatórias dos autores, tradutores ou editores a Machado de Assis. Esses exemplares, somados aos 15 encontrados por Glória Vianna, foram catalogados e numerados, totalizando cerca de 173 volumes, em sua grande parte de autoria de contemporâneos de Machado, tais como Lúcio de Mendonça, José Veríssimo, Júlio de Castilho, Souza Bandeira, Alfredo d'Escragnolle Taunay e Vicente de Carvalho.

Além disso, em nossa incursão pela biblioteca pessoal de Machado, nos deparamos com alguns dos volumes arrolados por Glória Vianna como desaparecidos, ${ }^{6}$ tais como toda a obra de Gustave Flaubert que se encontrava perdida, exceto o exemplar de Salammbô, ainda não localizado, e o exemplar da Bíblia Sagrada. Como nosso cotejo com a lista de Vianna não foi exaustivo, alertamos para o fato de esta última catalogação pública da biblioteca machadiana estar completamente defasada, sendo urgente a publicação de um catálogo atualizado das obras pertencentes a Machado, a

\footnotetext{
${ }^{5}$ Idem, p. 105.

${ }^{6}$ Para uma descrição detalhada desse percurso histórico e dos volumes listados como não encontrados por Glória Vianna, remetemos o leitor à pesquisa publicada em 2001.
} 
fim de permitir o acesso público a este, evitando que tais informações fiquem restritas ao âmbito da ABL. ${ }^{7}$

Percebe-se que a trajetória dessa biblioteca, com as suas perdas e possíveis enxertos, com todas as manipulações que sofreu ao passar por seus vários possíveis leitores, desde os herdeiros até os críticos que a catalogaram, denota a ingenuidade metodológica de se tomar uma dada catalogação de livros como a biblioteca completa de um escritor, já que

[...] a ausência de um livro das prateleiras desta biblioteca não significa que Machado não o tenha lido e, mesmo, não o tenha possuído nas prateleiras de sua biblioteca quando esta estava completa. Da mesma forma, sua presença não prova nada além de um eco, uma reminiscência, uma pista, um ar familiar que vem confirmar sua presença ou sua lembrança na obra de Machado de Assis. ${ }^{8}$

Além disso, se nosso interesse se volta para a observação da relação com discursos já-escritos operada no espaço da biblioteca particular de Machado, a correlação entre escrita e leitura merece ser aqui recolocada. De forma semelhante à precária constituição atual do acervo, a análise de possíveis marcas de leitura deixadas nos livros é algo bastante problemático, visto haver um apagamento sistemático desse trabalho de leitura, como aponta Glória Vianna:

Quanto às anotações feitas nos livros, pode-se afirmar que não era uma prática do escritor fazer considerações nas margens dos textos. É muito mais comum verificar-se marcações de leitura, prática que se observa em mais de $10 \%$ da coleção. Só observamos anotações em 4 volumes, mas não se pode garantir que tenham sido feitas pelo escritor. O professor Massa defende a ideia de que tais livros podem ter sido comprados de segunda mão, o que significa que já possuiriam anotações. $^{9}$

\footnotetext{
7 Apesar de existir um sistema de consulta on-line ao acervo da Biblioteca Lúcio de Mendonça, disponível no site da ABL (www.academia.org.br), o catálogo atualizado das obras da biblioteca machadiana não é possível de ser acessado em sua integralidade pelo público geral, já que o motor de busca permite que se encontrem as obras por palavra-chave, título, autor, assunto, editora, ISBN/ISSN, série e tipo de material, mas não pelo número de chamada, único indicativo do acervo ao qual o livro pertence, no nosso caso, o acervo pessoal de Machado de Assis.
}

${ }^{8}$ MASSA, Jean-Michel. A biblioteca de Machado de Assis, cit., p. 32, grifos nossos.

${ }^{9}$ VIANNA, Glória. Revendo a biblioteca de Machado de Assis, cit., p. 127. 
No entanto, se pretendemos observar a biblioteca de um escritor como o lugar privilegiado do encontro entre leitura e escrita, a fim de melhor compreender a interdiscursividade inerente à escritura machadiana, devemos ter em mente que estamos diante de um acervo metamorfoseado pelo curso arbitrário da história e pelo manejo de arquivistas e críticos literários que, ao organizarem e reordenarem os livros, estabelecem novas redes de sentido entre eles, totalmente diversas do relacionamento operado pelo escritor quando vivo. Apesar disso, a temática variada do acervo nos permite entrever um Machado-leitor voraz, consumindo livros de cunho não ficcional, da literatura inglesa, alemã, brasileira, portuguesa, italiana, latina, grega, além de um grande contingente de literatura francesa.

Frente a essa ingestão incansável, percebemos uma constante frequentação dos discursos já-escritos, da biblioteca, o que não é incoerente com o efeito de leitura percebido ao ler-se sua obra ficcional, recheada de citações, alusões e referências. Assim, visando compreender essa interdiscursividade que nos parece estar intimamente ligada a um procedimento específico de leitura e sem ter acesso a nenhum vestígio físico dessa relação com a biblioteca, buscaremos na própria obra ficcional a correlação possível entre leitura e escrita, buscando olhar aqui para a biblioteca ficcional imprimida na obra romanesca de Machado. Nosso interesse pela biblioteca real do escritor volta-se, então, para o que ela tem de virtual, para o que ela potencialmente nos aponta como sendo uma relação material e discursivamente mais fluida entre leitura e escrita, pensando-a como o lugar da enunciabilidade e da construção de um imaginário livresco que se forma entre o resto ambíguo da biblioteca real e a biblioteca ficcional, sem pretendermos detectar possíveis diálogos diretos, já que "[...] mesmo que contássemos com a biblioteca perfeitamente conservada e de fato tivéssemos certeza de que eventuais anotações foram produzidas por Machado, ainda assim não poderíamos estabelecer nenhuma relação imediata entre eventuais leituras e a obra do autor". ${ }^{10}$

Conforme ressalta João Cezar de Castro Rocha, devemos relativizar a busca pelos traços das "influências diretas" na biblioteca de Machado e procurar novas formas

\footnotetext{
${ }^{10}$ ROCHA, João Cezar de Castro. Machado de Assis, leitor (autor) da Revista do Instituto Histórico e Geográfico Brasileiro. In: JOBIM, José Luís (Org.). A biblioteca de Machado de Assis. Rio de Janeiro: ABL; Topbooks, 2001. p. 325. Grifos do autor.
} 
de abordá-la, visto que a biblioteca parece ser mobilizada pela escritura de maneira diversa, atuando mais como um potencial discursivo com o qual ou contra o qual o escritor trabalha, numa relação que nega qualquer tipo de relação direta e/ou hierárquica, conforme veremos a seguir, em um caso no qual verificamos uma cópia quase literal de um discurso já-escrito presente na biblioteca machadiana.

Em Esaú e Jacó é evidente o fato de o autor utilizar-se do discurso bíblico em sua trama ficcional, fazendo uso de referências, alusões e até mesmo citações de trechos, para as quais chamamos aqui a atenção. Como se pode verificar na obra publicada, em dois momentos específicos o narrador faz uso da citação de trechos da Bíblia com o objetivo de ilustrar a situação vivida pelas personagens, comparando-a com o evento narrado nas Escrituras. Um deles se dá no capítulo XV, intitulado "'Teste David cum Sibylla'", no qual o espírita Plácido, ao ser consultado por Santos acerca da briga dos gêmeos no ventre da mãe, revelada pela cabocla do Castelo, vê nos nomes escolhidos para os dois uma corroboração da briga e, para provar o desentendimento dos apóstolos Pedro e Paulo, cita um versículo bíblico:

Santos expôs então a consulta, gravemente, com um gesto particular que tinha de arregalar os olhos para arregalar a novidade. Não esqueceu nem escondeu nada; contou a própria ida da mulher ao Castelo, com desdém, é verdade, mas ponto por ponto. Plácido ouvia atento, perguntando, voltando atrás, e acabou por meditar alguns minutos. Enfim, declarou que o fenômeno, caso se houvesse dado, era raro, se não único, mas possível. Já o fato de se chamarem Pedro e Paulo indicava alguma rivalidade, porque esses dous apóstolos brigaram também.

- Perdão, mas o baptismo...

- Foi posterior, sei, mas os nomes podem ter sido predestinados, tanto mais que a escolha dos nomes veio, como o senhor me disse, por inspiração à tia dos meninos.

- Justamente.

- Dona Perpétua é muito devota.

- Muito.

- Creio que os próprios espíritos de São Pedro e São Paulo houvessem escolhido aquela senhora para inspirar os nomes que estão no Credo; advirta que ela reza muitas vezes o Credo, mas foi naquela ocasião que se lembrou deles.

- Exato, exato! 
O doutor foi à estante e tirou uma Bíblia, encadernada em couro, com grandes fechos de metal. Abriu a Epístola de São Paulo aos Gálatas, e leu a passagem do capítulo II, versículo 11, em que o apóstolo conta que, indo a Antioquia, onde estava São Pedro, "resistiu-lhe na cara". 11

Se cotejarmos a citação machadiana com a edição da Bíblia Sagrada presente no acervo da biblioteca de Machado, veremos uma quase coincidência textual, ficando evidente a cópia: "Ora tendo vindo Céfas a Antioquia: eu lhe resisti na cara, porque era reprehensivel."12 Percebe-se, todavia, duas mudanças mínimas operadas pelo texto machadiano; a primeira é a inversão de papéis entre as personagens: parecendo pouco preocupado em seguir à risca o texto citado, na paráfrase da contextualização do evento bíblico, o narrador afirma que Paulo é quem chega em Antioquia, onde estava Pedro, enquanto que na Bíblia o que se dá é o contrário. Em seguida, ao transcrever o trecho, revela-se uma tensão operada pela escrita machadiana com relação à oralidade, já que o narrador acaba por solapar a colocação pronominal em próclise do original, "lhe resisti", mais condizente com o falar brasileiro, para empregar a forma preconizada pela normatização gramatical, que recomenda a ênclise, "resisti-lhe".

O outro momento no qual um trecho bíblico é citado ipsis litteris ocorre no capítulo XLVII, intitulado "São Mateus, IV, 1-10", no qual D. Cláudia tenta convencer Batista a passar para o lado dos liberais, a fim de permitir que o marido consiga uma presidência de província. Ao final da disputa verbal encetada entre as duas personagens, o narrador cita um trecho do evangelho de São Mateus, estabelecendo um paralelo entre a situação relatada no excerto bíblico - a tentação de Cristo no deserto - e a situação das personagens, na qual a esposa de Batista estaria desempenhando o papel do Diabo:

[...] O pai abraçou-a [Flora] com amor, e perguntou-lhe se queria ir para alguma província, sendo ele presidente.

- Mas os conservadores não caíram?

- Caíram, sim, mas supõe que...

\footnotetext{
11 ASSIS, Machado de. Esaú e Jacob. Rio de Janeiro; Brasília: Civilização Brasileira; INL (Comissão Machado de Assis), 1975 [1904]. p. 93-4.

${ }^{12}$ BIBLIA SAGRADA, contendo o velho e o novo testamento; traduzida em portuguez segundo a vulgata latina, por Antonio Pereira de Figueiredo. Londres: Officina de Harrison e filhos, 1866. p. 1143.
} 
- Ah! Não, papai!

- Não, por quê?

- Não desejo sair do Rio de Janeiro.

Talvez o Rio de Janeiro para ela fosse Botafogo, e propriamente a casa de Natividade. O pai não apurou as causas da recusa; supô-las políticas, e achou novas forças para resistir às tentações de Dona Cláudia: "Vai-te, Satanás; porque escripto está: Ao Senhor teu Deus adorarás, e a ele servirás." E seguiu-se como na Escriptura: "Então o deixou o Diabo; e eis que chegaram os anjos e o serviram." Os anjos foram só um, que valia por muitos; e o pai lhe disse beijando-a carinhosamente:

- Muito bem, muito bem, minha filha.

- Não é, papai?

Não, não foi a filha que tolheu a deserção do pai. Ao contrário. Baptista, se tivesse de ceder, cederia à mulher ou ao Diabo, sinônimos neste capítulo. ${ }^{13}$

Consultando a Bíblia presente na biblioteca pessoal de Machado, encontramos o trecho citado, que sugere uma transposição quase exata, uma cópia do excerto: "Então lhe disse Jesus: Vai-te Satanás: Porque escrito está: Ao Senhor teu Deos adorarás, e a elle só servirás. // Então o deixou o diabo: e eis-que chegárão os anjos, e o servião". ${ }^{14}$

Vê-se que, mesmo quando o excerto é retomado em sua integralidade, sem mudanças, não aparecem marcas de leitura no volume original, apontando para a dificuldade em se verificar materialmente os procedimentos de leitura do autor, levando-nos a observar a tensão estabelecida na própria ficção, na biblioteca ficcional. Dessa forma, ao observarmos a transposição do texto bíblico, pelo simples fato de este estar em outro contexto, sendo regido por lógicas discursivas diferentes, ele já é modificado de alguma forma, mesmo que se mantenha o discurso alheio sem alterações. Lembramos aqui a ideia borgiana da reescrita do Quixote por Pierre Menard: ${ }^{15}$ a cópia exata do texto de Cervantes nos dias atuais não gera um plágio, mas paradoxalmente dá lugar a um texto novo, completamente diferente do original, uma vez que escrever o Quixote hoje tem implicações diversas de se escrever o Quixote na época de Cervantes.

\footnotetext{
${ }^{13}$ ASSIS, Machado de. Esaú e Jacob, cit., p. 150-1.

${ }^{14}$ BIBLIA SAGRADA, cit., p. 933.

15 BORGES, Jorge Luis. Pierre Menard, autor del Quijote. In: Obras completas I. Barcelona:
} Emecé Editores, 1989 [1944]. p. 444-450. 
Percebe-se que a distância histórica que nos separa do contexto de produção da obra cervantina é que é determinante para a ressignificação da reescrita da obra, fazendo com que sua cópia em outro tempo e espaço, ou seja, sua enunciação segundo outras condições de produção, gere uma obra necessariamente original.

Desse modo, a cópia da Bíblia no texto de Machado, ao deslocar o texto sagrado de seu contexto de produção, já faz com que o texto reescrito seja outro. Além disso, no texto ficcional, não estamos mais diante da mesma lógica discursiva: se na Bíblia a baliza para se compreender o que é dito encontra-se sobretudo na ideia de que se veicula uma verdade, no texto do romancista temos o pressuposto de que tudo o que é lido deve ser encarado como ficcional, como algo construído, isto é, como artifício, visto estar subentendida em toda leitura romanesca uma disposição de leitura que prevê que tudo ali seja lido como literatura.

Em segundo lugar, vemos que o texto machadiano arrola a citação bíblica, no primeiro caso, de maneira que esta venha a ser usada por uma personagem a fim de justificar e corroborar a predição da cabocla, esta carregada de misticismo. A justaposição de um texto tido como sagrado a uma situação tida como profana nivela os dois contextos, transformando o que era legatário de uma verdade unívoca em mais uma predição mística e incontestável logicamente, já que o discurso sagrado, assim como a predição da cabocla, se revela igualmente regido pela baliza da crença: ou se acredita ou não se acredita em sua pretensa "veracidade". Vemos que o texto bíblico é manipulado pela personagem, a fim de confirmar algo que não pode ser confirmado ou demonstrado de maneira nenhuma, uma vez que a predição, assim como tudo o que envolve a crença religiosa, não é passível de ser explicada e demonstrada logicamente. Percebe-se que a verdade bíblica se perde, já que esta, equiparada à predição, é igualmente discutível e hipotética.

Além disso, o texto machadiano opera uma ironia fina ao proceder a essa equiparação, colocando em relevo no próprio título do capítulo, e em seguida na fala da personagem, a comparação entre o profano e o sagrado, através da expressão "Teste David cum Sibylla", que aponta justamente para o fato de um "oráculo" equivaler e provar o outro, no que concerne à inquietação da personagem: 
Deixe às senhoras as suas crenças da meninice, concluiu; se elas têm fé na tal mulher do Castelo, e acham que é um veículo de verdade, não as desminta por ora. Diga-lhes que eu estou de acordo com o seu oráculo. Teste David cum Sibylla. ${ }^{16}$

A ironia é igualmente reforçada quando a personagem, logo após ler a citação bíblica apresentada por Plácido e deixando-se levar pela predição bíblica, vê em todos os menores fatos indícios que corroboram o oráculo, fazendo com que até os números do capítulo e versículo da citação comprovem o presságio anunciado:

- Leia: "resisti-lhe na cara."

Santos leu e teve uma ideia. As ideias querem-se festejadas, quando são belas, e examinadas, quando novas; a dele era a um tempo nova e bela. Deslumbrado, ergueu a mão e deu uma palmada na folha, bradando:

- Sem contar que este número onze do versículo, composto de dous algarismos iguais, 1 e 1, é um número gêmeo, não lhe parece?

- Justamente. E mais: o capítulo é o segundo, isto é, dous, que é o próprio número dos irmãos gêmeos. ${ }^{17}$

Em seguida, as personagens continuam a cogitar e Santos deixa-se levar por uma espécie de rêverie, aventando uma nova hipótese, então inspirada pelo espiritismo, centrada na ideia da reencarnação, ampliando ainda mais o leque de conjecturas balizadas pela crença, mas desencadeadas por indícios mínimos e pouco convincentes, ironicamente descritos como "substanciais", tais como os números dobrados, a suposta briga dos gêmeos no ventre da mãe e a suposta inspiração divina dos nomes de Pedro e Paulo:

Mistério engendra mistério. Havia mais de um elo íntimo, substancial, escondido, que ligava tudo. Briga, Pedro e Paulo, irmãos gêmeos, números gêmeos, tudo eram águas de mistério que eles agora rasgavam, nadando e bracejando com força. Santos foi mais ao fundo; não seriam os dous meninos os próprios espíritos de São Pedro e de São Paulo, que renasciam agora, e ele, pai dos dous apóstolos?... A fé

\footnotetext{
${ }^{16}$ ASSIS, Machado de. Esaú e Jacob, cit., p. 95.

${ }^{17}$ ASSIS, Machado de. Esaú e Jacob, cit., p. 94.
} 
transfigura; Santos tinha um ar quase divino, trepou em si mesmo, e os olhos, ordinariamente sem expressão, pareciam entornar a chama da vida. Pai de apóstolos! E que apóstolos! Plácido esteve quase, quase a crer também, achava-se dentro de um mar torvo, soturno, onde as vozes do infinito se perdiam, mas logo lhe acudia que os espíritos de São Pedro e São Paulo tinham chegado à perfeição; não tornariam cá. Não importa; seriam outros, grandes e nobres. Os destinos podiam ser brilhantes; tinha razão a cabocla, sem saber o que dizia. ${ }^{18}$

Nota-se que a descrição é permeada por algumas imagens muito próximas de lugares-comuns de efeito romântico, que reforçam o aspecto irônico do excerto, mostrando o ridículo das suposições das personagens. O texto bíblico é, portanto, contaminado pela ironia do texto machadiano, contribuindo para o rebaixamento do texto original.

Nesse mesmo sentido, na outra citação do texto das Escrituras, também temos um rebaixamento do texto bíblico, visto que este é comparado pelo narrador a uma reles situação cotidiana. Ao colocar lado a lado as tentações de D. Cláudia - que deseja que seu marido abandone os conservadores e se declare liberal, a fim de conseguir vantagens pessoais, já que estes estavam então no poder - e a tentação de Cristo no deserto, esta última vê-se diminuída, uma vez que serve para ilustrar um caso comezinho decorrente da dança política de alternância entre liberais e conservadores. Apontando o despropósito da comparação, dada a distância e a desproporção entre as situações, a aproximação subjacente à inserção do texto bíblico, a saber, Satanás-D. Cláudia-liberais, Cristo-Batista-conservadores e anjos do céu-Flora, mas explicitada pelo narrador, ao colocar D. Cláudia e o Diabo como "sinônimos neste capítulo", se torna, no mínimo, risível, já que a luta maniqueísta entre o bem e o mal, Deus e Diabo, da Bíblia é justaposta à mera alternância política entre partidos e aos interesses pessoais de uma personagem. A própria oposição entre bem e mal, entre Deus e Diabo, ao ser nivelada à oposição entre conservadores e liberais, é relativizada, senão extinta, visto o que é comparado à oposição maniqueísta máxima aparecer no próprio texto como algo relativo, onde os opostos quase que se equivaleriam: "- Você estava com eles [os conservadores], como a gente está num baile, onde não é preciso ter as mesmas ideias

${ }^{18}$ Idem, p. 95. 
para dançar a mesma quadrilha". ${ }^{19} \mathrm{O}$ despropósito da comparação risível, ao esvaziar o sentido do texto bíblico e ironizá-lo, acaba por afetar o próprio procedimento da citação, visto como um artifício igualmente risível e rebaixado.

Assim sendo, o leitor depara-se com a referência a um texto que lhe é familiar, fazendo com que este reconheça a narrativa como válida e como inserida numa tradição de outros textos, mas esse texto aparece de maneira rebaixada e dessacralizada. Frente à necessidade de citar, para que sua narrativa seja reconhecida, resta o recurso de dessacralizar o texto - tornando sua verdade unívoca não apenas relativizada e ironizada, mas também inócua - e de apontar para a citação como algo artificialmente construído e imposto.

Ivo Barbieri, em artigo no qual busca relacionar as leituras machadianas realizadas em sua biblioteca e os seus ecos presentes na obra ficcional, no que concerne à reescrita dos discursos da psicologia, percebe que os discursos já-escritos apareceriam na obra do escritor a contrapelo deles mesmos, visando estabelecer um afastamento com relação ao discurso alheio original. Ao buscar as formas de reapropriação do livro Les maladies de la mémoire de Ribot no conto machadiano "O lapso", o crítico destaca que

A leitura em paralelo dos dois textos, o do ficcionista e o do psicólogo, produz o efeito de um diálogo intertextual gerador de espaço semântico contraditório pois que, articulado à base de unidades lexicais convergentes, gera significados divergentes. É que táticas e estratégia divergem de um para outro texto. Enquanto a exposição do psicólogo apresenta-se com a gravidade de quem pretende ter alcançado uma nova verdade científica e, para enunciá-la, necessita elaborar um discurso coeso e convincente, a narrativa do ficcionista desmascara, sob a aparência de falsa seriedade, a inconsistência da construção monolítica e presunçosa. Imitando a forma retórica do discurso pseudocientífico, Machado inverte-lhe o sentido, bem ao gosto da paródia estilística. ${ }^{20}$

Desse modo, Machado operaria uma importante mudança discursiva ao incluir em sua obra discursos - ou restos de discursos - já-escritos, uma vez que, ao fazer uso

\footnotetext{
${ }^{19}$ Idem, p. 149.

${ }^{20}$ BARBIERI, Ivo. O lapso ou uma psicoterapia do humor. In: JOBIM, José Luís (Org.). A biblioteca de Machado de Assis. Rio de Janeiro: ABL; Topbooks, 2001. p. 342-343.
} 
de uma retórica pseudocientífica num contexto irônico, acaba minando a univocidade de sentido do discurso original: a verdade científica torna-se mera ficção risível. Segundo Barbieri, a principal forma machadiana de reapropriação de discursos alheios, responsável por esse efeito que ele denomina de "dessacralizador", ${ }^{21}$ seria a descontextualização discursiva: "Descontextualizando categorias e enunciados, emendaos em novos contextos, construindo novos textos, os seus, sobre as ruínas de textos desmoronados". ${ }^{22}$

É interessante, pois, observar que a reescrita machadiana do já-dito não se faz na ordem da continuação passiva de uma biblioteca, mas sim dentro de uma perspectiva de contraposição a discursos alheios. Apesar de subentendida na ficção de Machado, visto que sua trama ficcional aponta justamente para seu aspecto interdiscursivo e sua própria enunciabilidade não parece ser possível fora dessa relação intrínseca com os discursos já-escritos, a biblioteca aparece para ser negada: ela está subentendida em negativo na obra. ${ }^{23}$

Dada a relação predominantemente irônica ou de rebaixamento que Machado parece estabelecer com esses discursos e com o próprio procedimento de citar, lendo-os a contrapelo ou diminuindo-os ao utilizá-los para narrar coisas comezinhas, sem se apropriar da biblioteca como portadora de uma verdade absoluta, mas tornando os discursos ambíguos, notamos que a referência a esses discursos parece ser caracterizadora de uma necessidade imperiosa e dúbia de se relacionar com uma instituição discursiva, que revela uma problemática própria à literatura brasileira da época machadiana: como fazer literatura no Brasil dos Oitocentos? Quais suas condições de enunciabilidade e de legibilidade? Com quem e contra quem se relaciona ao fazer literatura? Onde se insere a literatura brasileira? E talvez a pergunta mais difícil de ultrapassar: existe literatura no Brasil de Machado? Assim, a necessidade de se relacionar com outros discursos parece ser uma saída possível para dar existência a essa

\footnotetext{
21 "circuito dessacralizador do procedimento machadiano" (BARBIERI, Ivo. O lapso ou uma psicoterapia do humor. In: JOBIM, José Luís [Org.]. A biblioteca de Machado de Assis. Rio de Janeiro: ABL; Topbooks, 2001. p. 345).

${ }^{22}$ Idem, p. 344.

${ }^{23}$ Igualmente nesse sentido de uma escrita que se contrapõe à biblioteca, remetemos nosso leitor ao trabalho de Leonardo Vieira de Almeida: ALMEIDA, Leonardo Vieira. A questão da biblioteca em Memórias póstumas de Brás Cubas. In: ROCHA, João Cezar de Castro (Org.). À roda de Machado de Assis: ficção, crônica e crítica. Chapecó (SC): Argos, 2006. p. 129-154.
} 
"literatura em formação", ${ }^{24}$ como se a escritura machadiana, confrontada com a necessidade de inserir-se numa tradição ou na rede de discursos já-escritos, para escrever, para fazer literatura, para tornar nossa literatura legível, para construir um campo, decidisse assim o fazer, mas de forma crítica, lendo a contrapelo e mostrando de forma irônica o próprio procedimento escritural. Nesse caso, os discursos já-escritos, ou a biblioteca, se imporiam como uma instituição artificiosa.

No entanto, é interessante reforçar que, como vimos no caso da leitura machadiana do texto bíblico, o efeito crítico percebido através da inclusão enviesada de discursos já-escritos, que dá a ver a necessidade de relacionamento com uma biblioteca artificiosamente imposta como condição de legitimação do discurso literário, acaba por atingir o próprio procedimento da citação: não apenas os discursos citados são ironizados e "desmoronados" pela ficção machadiana, mas a necessidade imperiosa de citar é também colocada de maneira irônica e desvelada enquanto um artifício igualmente "dessacralizado", que não mais manifesta o lugar da inserção da erudição ou do tópos da emulação, mas apenas ocupa um vazio a ser convencionalmente preenchido.

Nesse sentido, identificamos em Memórias póstumas de Brás Cubas um excerto no qual o gesto de citar é realizado de maneira irônica, como uma forma de legitimação discursiva socialmente imposta. Trata-se do segundo parágrafo do capítulo CXXIV, intitulado "Vá de intermédio", passagem presente na versão seriada de 1880 , publicada na Revista Brazileira, e na primeira edição em livro de 1881, porém suprimida a partir da segunda edição de 1896, segundo aponta o cotejo realizado pela Comissão Machado de Assis para as edições críticas das obras do autor, que trazem em nota de rodapé as variações entre as edições. Citamos o capítulo em sua integralidade, conforme a versão das duas primeiras edições, incluindo-se o excerto suprimido:

Que há entre a vida e a morte? Uma curta ponte. Não obstante, se eu não compusesse este capítulo, padeceria o leitor um forte abalo,

\footnotetext{
${ }^{24}$ Esse aspecto da escrita machadiana foi abordado por João Cezar de Castro Rocha em uma conferência realizada na Universidade de São Paulo (ROCHA, João Cezar de Castro. Machado de Assis e a poética da emulação. Palestra proferida na USP, São Paulo, 03 de novembro 2010.), na qual o crítico buscou relacionar os recursos formais de Machado, identificáveis ao campo da emulatio-imitatio, a uma estratégia para fazer frente a situações assimétricas de inferioridade/dependência socioculturais próprias da relação entre países não hegemônicos e o cânone, apontando para o fato de as práticas de escrita no Brasil oitocentista pressuporem a necessidade de citar a tradição europeia.
} 
assaz danoso ao efeito do livro. Saltar de um retrato a um epitáfio, pode ser real e comum; o leitor, entretanto, não se refugia no livro, senão para escapar à vida. Não digo que este pensamento seja meu; digo que há nele uma dose de verdade, e que, ao menos, a forma é pitoresca. E repito: não é meu.

Vá de intermédio, e contemos a este propósito uma anedocta. Foi no tempo da minha vida parlamentar; éramos cinco; falávamos de cousas e lousas, e aconteceu tocar nos negócios do Rio da Prata. Então disse um: - O governo não deve esquecer que o dinheiro é o nervo da guerra. Ao que eu redargui que não, que o nervo da guerra eram os bons soldados. Um dos ouvintes coçou o nariz, outro consultou o relógio, o terceiro tamborilou sobre o joelho, o quarto deu algumas pernadas pela sala, o quinto era eu. Mas, continuando a falar, ponderei que essa idéa, inteiramente justa, não era minha, e sim de Machiavelli; circunstância que levou o primeiro a não coçar o nariz, o segundo a não consultar o relógio, o terceiro a não tamborilar sobre o joelho, e o quarto a não dar pernadas; e todos me rodearam, e me pediram que repetisse o dito, e repeti, e eles extasiavam-se, e batiam com a cabeça aprovando, saboreando, decorando. O que estimei, porque fui sempre amador de idéas justas. Mas vamos ao epitáfio. ${ }^{25}$

Nesse capítulo, intercalado entre a descrição do caráter de Cotrim e o epitáfio que serve de anúncio para a morte de Nhã-loló, com quem Brás Cubas se casaria, o narrador, valendo-se da oportunidade aberta pela revelação de que ele coloca em sua narração pensamentos que não são de sua autoria, aproveita para contar uma anedota que, na verdade, ficcionaliza ironicamente a recepção que procedimentos citacionais obtêm em um determinado contexto social. No episódio aventado, percebe-se que a estrutura narrativa opõe dois cenários que se desenham, primeiramente, a partir da frase de Brás Cubas, que discorda de seu interlocutor, e, em seguida, a partir da indicação da autoria da frase, o que revela a inclusão no discurso da personagem do recurso à citação. A frase citada de Maquiavel, afirmando que o nervo da guerra são os bons soldados, constitui-se em uma sentença simples, fundada na percepção de que a guerra se faz fisicamente por seus agentes mais imediatos, aqueles que estão em combate, os bons soldados, revelando um aspecto óbvio e mais do que evidente das batalhas, e opõe-se à frase anterior, afirmando que o nervo da guerra é o dinheiro, sentença igualmente simples, mas que busca observar os aspectos subjacentes ao corpo-a-corpo visível da guerra, saindo do primeiro plano inicial do combate literal para encontrar num segundo

\footnotetext{
25 ASSIS, Machado de. Memórias póstumas de Brás Cubas. Rio de Janeiro; Brasília: Civilização Brasileira; INL (Comissão Machado de Assis), 1975 [1881]. p. 269-270. Grifos nossos.
} 
plano o dinheiro como o interesse e o vetor implícitos. A frase, na boca de Brás Cubas, soa como uma trivialidade desmerecedora da atenção dos interlocutores, que reagem calados, de maneira a demonstrar algo semelhante ao enfado, exercendo gestos próprios a cacoetes ordinários para passar o tempo: "Um dos ouvintes coçou o nariz, outro consultou o relógio, o terceiro tamborilou sobre o joelho, o quarto deu algumas pernadas pela sala".

Todavia, ao revelar que a ideia, recebida por todos com indiferença, não era de autoria da personagem, mas sim de um autor consagrado no âmbito das questões políticas, Maquiavel, nota-se uma mudança brusca na reação dos ouvintes de Brás Cubas, exposta primeiramente por uma negação sequencial das ações apáticas anteriores: "circunstância que levou o primeiro a não coçar o nariz, o segundo a não consultar o relógio, o terceiro a não tamborilar sobre o joelho, e o quarto a não dar pernadas". A repetição negativada das ações já descritas, além de reforçar o tom de anedota risível, sublinha a diametral diferença entre a atitude dos interlocutores, apontando ironicamente a relatividade da recepção de uma mesma frase. Após a indicação da autoria verdadeira do excerto, que revela o estratagema do recurso ao discurso alheio e ao mesmo tempo legitima e autoriza o discurso de Brás Cubas, seus ouvintes demonstram uma ímpar consideração e entusiasmo pela fala da personagem, chegando a extasiarem-se, a saborear e decorar a frase, já que a mera indicação de que se tratava de um argumento de autoridade transformava o discurso citado em um enunciado merecedor de fruição e da disposição de ser repetido, isto é, reinserido em outras ocasiões sociais.

A anedota, ao mostrar o antagonismo contido na dupla recepção de uma mesma frase, cuja relatividade reside na indicação da fonte enunciativa primeva, torna a atitude dos interlocutores de Brás risível, na medida em que eles se entusiasmam apenas posteriormente com aquilo que num primeiro momento não era merecedor de atenção, jogando o interesse pelo que é dito para fora do âmbito do próprio enunciado. Assim, aponta-se de forma irônica a maneira pela qual um discurso é legitimado: não pelo que é dito, nem pela inclusão silenciosa de discursos autorizados, mas pela revelação explícita do recurso ao uso de citações legitimadoras. 
Percebe-se que a ironia machadiana não se limita, portanto, apenas aos discursos citados em si, mas estende-se ao procedimento de citar, revelado em sua imposição convencional. Mais uma vez, frente a práticas de escrita que impõem a necessidade de citar o cânone literário para se consolidar enquanto discurso legitimado, a ficção machadiana vai minar os procedimentos literários, permeando a tudo com uma ironia da qual não escapa nem o leitor: se os interlocutores de Brás são ridículos porque valorizam a citação como recurso legitimador, a ficção de Machado nos oferece justamente uma literatura plena de citações e alusões que parecem agradar a um leitor ávido de discursos autorizados por sua relação com o cânone... Dessa ironia que não poupa ninguém, apontando para os procedimentos de escrita e de leitura impostos para que uma obra seja dizível e legível, parece-nos que um dos efeitos primordiais seria o questionamento das próprias estruturas que permitem a enunciabilidade e a legibilidade da literatura brasileira oitocentista, problematizando as relações possíveis entre as práticas de escrita e as práticas de leitura.

Nesse sentido, é interessante observar outro excerto do romance, o do capítulo XXIV, "Curto, mas alegre", que sucede a narração da morte da mãe de Brás Cubas, no qual a personagem coloca, de forma bastante irônica, a citação de discursos alheios e as frases feitas como um ornamento discursivo:

Fiquei prostrado. E contudo era eu, nesse tempo, um fiel compêndio de trivialidade e presunção. Jamais o problema da vida e da morte me oprimira o cérebro; nunca até esse dia me debruçara sobre o abismo do Inexplicável; faltava-me o essencial, que é o estímulo, a vertigem...

Para lhes dizer a verdade toda, eu reflectia as opiniões de um cabeleireiro, que achei em Modena, e que se distinguia por não as ter absolutamente. Era a flor dos cabeleireiros; por mais demorada que fosse a operação do toucado, não enfadava nunca; ele intercalava as penteadelas com muitos motes e pulhas, cheios de um pico, de um sabor... Não tinha outra filosofia. Nem eu. Não digo que a Universidade me não tivesse ensinado alguma; mas eu decorei-lhe só as fórmulas, o vocabulário, o esqueleto. Tratei-a como tratei o latim: embolsei três versos de Virgílio, dous de Horácio, uma dúzia de locuções morais e políticas, para as despesas da conversação. Trateios como tratei a história e a jurisprudência. Colhi de todas as cousas a fraseologia, a casca, a ornamentação...

Talvez espante ao leitor a franqueza com que lhe exponho e realço a minha mediocridade; advirta que a franqueza é a primeira virtude de 
um defuncto. ${ }^{26}$

Nesse trecho, após revelar mais uma vez que acabara de usar uma opinião alheia, citando o discurso do outro, neste caso de um cabeleireiro italiano, Brás Cubas aborda com ironia a questão da inclusão de ornamentos no discurso. Tratando aqui da repetição de fórmulas, frases feitas e citações como legitimação para seu discurso, o defunto autor narra como empreendeu seus estudos na universidade, decorando apenas a roupagem discursiva - "as fórmulas, o vocabulário, o esqueleto" - das ciências, tais como a história, a jurisprudência, a filosofia e o latim, a fim de poder inseri-la posteriormente em seu discurso, ornado de versos de Virgílio e de Horácio, de "locuções morais e políticas". Todo o procedimento de aproveitamento apenas do básico do que a universidade lhe oferecera, para apenas fingir uma sapiência que ele não possuía, é ironicamente caracterizado pela personagem como uma "mediocridade", cuja exposição e realce deveriam espantar o leitor, mas que acaba por revelar criticamente o próprio artifício empregado ao longo de todas as Memórias: como não lembrar aqui que o livro que lemos é igualmente recheado de frases feitas, de citações e de uma verborragia estéril ${ }^{27}$

O método medíocre concernente ao estudo das ciências, apontado como meio de adquirir o ornamento discursivo a ser empregado nas "despesas da conversação", ou seja, para legitimar seu discurso nas conversas banais das rodas sociais, é também aquele que agrega ao discurso "a fraseologia, a casca, a ornamentação", sublinhando a mediocridade de Brás. Respingados pela mediocridade parecem estar a própria obra que recorre às citações e a todas as convenções romanescas para legitimar-se enquanto literatura, apesar de igualmente apontá-las como artificialmente impostas - e o leitor figurado como sequioso de uma literatura reconhecida como legítima e como legível, segundo as condições de legibilidade impostas. Buscando trabalhar ficcionalmente com

\footnotetext{
${ }^{26}$ ASSIS, Machado de. Memórias póstumas de Brás Cubas, cit., p. 146.

${ }^{27}$ Para um aprofundamento acerca dessa verborragia estéril, presente em Machado de Assis e Gustave Flaubert, no que se refere à repetição de clichês que, por sua iteratividade, instauram o silenciamento da narrativa, desvinculando-a de uma comunicabilidade possível e constituindo uma "tagarelice das ideias feitas", remetemos à dissertação de Lívia Cristina Gomes: GOMES, Lívia Cristina. Machado com Flaubert ou a política da escrita. 2011. 112 f. Dissertação (Mestrado em Estudos Linguísticos, Literários e Tradutológicos em Francês) - Faculdade de Filosofia, Letras e Ciências Humanas, Universidade de São Paulo, São Paulo, 2011.
} 
a problemática circundante à enunciabilidade e à legibilidade da própria literatura, percebemos que a biblioteca ficcional machadiana parte da biblioteca real para extrapolá-la e questioná-la, apontando para a tradição literária como algo imposto, dando a ler uma ficção marcada pela ironia tagarela do defunto autor.

Nesse sentido, a voz indefinida e problemática de Brás Cubas, pretensamente enunciada a partir do inverossímil além-túmulo, reencontra a tensão com o já-escrito efetuada na biblioteca real, colocando-se numa contraposição crítica a ela, já que a própria caracterização de um autor ficcional morto inviabiliza qualquer possibilidade de legado, através de uma voz tagarela que opera um deslocamento com relação à tradição e não funda - ou, ao menos, não pretende fundar - nenhuma genealogia, como, aliás, evidencia o próprio narrador ao desvelar as negativas e o saldo da derradeira negativa da sua trajetória de vida, no revelador e famoso capítulo CLX, "Das negativas", que fecha o livro deixando o leitor numa espécie de terra arrasada, da qual nada se salva, visto o saldo-negativo ser a impossibilidade máxima de continuidade: "[...] ao chegar a este outro lado do mistério, achei-me com um pequeno saldo, que é a derradeira negativa deste capítulo de negativas: - Não tive filhos, não transmiti a nenhuma criatura o legado da nossa miséria." 28

Dessa forma, com uma interdiscursividade problematizada pela escritura, Machado de Assis tece uma fina reflexão sobre as possibilidades enunciativas de sua literatura, ao construir uma ficção autorreflexiva que coloca em questão, e a descoberto, as condições e as implicações de se fazer literatura em dado contexto. A interdiscursividade operada pelo procedimento da citação irônica e dessacralizadora e essa autorreflexividade própria de sua escritura parecem fazer frente a uma questão própria de uma literatura "em formação" que, devido a seu impasse constitutivo, coloca justamente em relevo na trama ficcional quais as condições e as decorrências de se escrever literatura nos Oitocentos, através de um movimento que visa "incorporar à escrita as condições precárias do ambiente cultural", ${ }^{29}$ decorrentes de uma problemática interna ao próprio sistema literário que se via confrontado à precariedade do público leitor.

\footnotetext{
${ }^{28}$ ASSIS, Machado de. Memórias póstumas de Brás Cubas, cit., p. 301.

${ }^{29}$ GUIMARÃES, Hélio de Seixas. Os leitores de Machado de Assis: o romance machadiano e o público de literatura no século 19. São Paulo: Nankin; Edusp, 2004. p. 120.
} 
Nesse sentido, Hélio de Seixas Guimarães afirma que, confrontada com a evidência de um público leitor diminuto - escassez decorrente dos altos índices de analfabetismo e da concorrência exercida pelos romances europeus que entravam no país e caíam no gosto do público -, que apontaria para a inexistência de um campo ou sistema literários no Brasil, ou, ao menos, para a dificuldade em se fazer literatura sem um público leitor consistente, a ficção machadiana introjetaria essa problemática ao operar uma ficcionalização dos leitores, sobretudo a partir das Memórias póstumas de Brás Cubas, sublinhando a "precariedade e instabilidade de toda comunicação assim como de qualquer forma de conhecimento". ${ }^{30}$

Percebemos, desse modo, que a escrita de Machado se confunde com uma leitura que se faz de forma enviesada, a contrapelo da tradição ou dos discursos jáescritos, numa relação preponderantemente crítica da literatura consigo mesma, já que a enunciabilidade da obra e suas condições, ou ao menos a problemática circundante a esta, são reveladas por uma estrutura ficcional autorreflexiva e interdiscursiva. Assim, estabelece-se uma relação muito particular com o literário e com seus elementos, numa narrativa que se dobra sobre si mesma, ficcionalizando o que é próprio à literatura, para construir um discurso que é como uma biblioteca, dada a sua intrínseca interdiscursividade, delineando uma prática de escrita que se quer reveladora de si mesma, assumindo uma postura preponderantemente crítica com relação a seu próprio discurso ficcional e com relação às suas condições de enunciabilidade e de legibilidade de forma ampla, ao questionar e problematizar os processos de escrita e de leitura, desnaturalizando as formas de ler e de escrever e apontando a artificialidade da própria instituição literária imposta. O efeito crítico dessa escritura estabelecida a partir de uma biblioteca real extrapolada pela ficção é, pois, vertiginoso, retroagindo sobre o próprio fazer literário e sobre a condição de existência da literatura brasileira, já que as regras do jogo literário aparecem desveladas e questionadas pela escritura de Machado de Assis.

Assim, ao revelar a citação como um procedimento artificioso que legitima a obra ao incluí-la numa rede de textos já-escritos e que constituem o fazer literário, questionam-se os procedimentos segundo os quais uma obra é enunciável e legível,

\footnotetext{
${ }^{30}$ Idem, p. 288.
} 
deixando entrever a ficção machadiana como um gesto que se contrapõe às formas de escrever e de dar a ler ficção que estavam sendo forjadas em sua época, forçando o leitor a ler um romance obtuso e a reencontrar, por meio das veredas de uma biblioteca igualmente obtusa, a questão primordial - e talvez jamais resolvida - da crítica literária: "o que é literatura?".

Referências:

ALMEIDA, Leonardo Vieira. A questão da biblioteca em Memórias póstumas de Brás Cubas. In: ROCHA, João Cezar de Castro (Org.). À roda de Machado de Assis: ficção, crônica e crítica. Chapecó (SC): Argos, 2006, p. 129-154.

ASSIS, Machado de. Esaú e Jacob. Rio de Janeiro; Brasília: Civilização Brasileira; INL (Comissão Machado de Assis), 1975 [1904].

ASSIS, Machado de. Memórias póstumas de Brás Cubas. Rio de Janeiro; Brasília: Civilização Brasileira; INL (Comissão Machado de Assis), 1975 [1881].

ASSIS, Machado de. Testamento. Arquivos da ABL. Firmado a 31 de maio de 1906. Citado por: VIANNA, Glória. Revendo a biblioteca de Machado de Assis. In: JOBIM, José Luís (Org.). A biblioteca de Machado de Assis. Rio de Janeiro: ABL; Topbooks, 2001. p. 99-274.

BARBIERI, Ivo. O lapso ou uma psicoterapia do humor. In: JOBIM, José Luís (Org.). A biblioteca de Machado de Assis. Rio de Janeiro: ABL; Topbooks, 2001. p. 335-347.

BIBLIA SAGRADA, contendo o velho e o novo testamento; traduzida em portuguez segundo a vulgata latina, por Antonio Pereira de Figueiredo. Londres: Officina de Harrison e filhos, 1866.

BORGES, Jorge Luis. Pierre Menard, autor del Quijote. In: Obras completas $I$. Barcelona: Emecé Editores, 1989 [1944]. p. 444-450.

GOMES, Lívia Cristina. Machado com Flaubert ou a política da escrita. 2011. 112 f. Dissertação (Mestrado em Estudos Linguísticos, Literários e Tradutológicos em Francês) - Faculdade de Filosofia, Letras e Ciências Humanas, Universidade de São Paulo, São Paulo, 2011.

GUIMARÃES, Hélio de Seixas. Os leitores de Machado de Assis: o romance machadiano e o público de literatura no século 19. São Paulo: Nankin; Edusp, 2004.

JOBIM, José Luís. Introdução. In: (Org.). A biblioteca de Machado de Assis. Rio de Janeiro: ABL; Topbooks, 2001. p. 9-19. 
MASSA, Jean-Michel. A biblioteca de Machado de Assis. In: JOBIM, José Luís (Org.). A biblioteca de Machado de Assis. Rio de Janeiro: ABL; Topbooks, 2001/ p. 21-90.

ROCHA, João Cezar de Castro. Machado de Assis e a poética da emulação. Palestra proferida na USP, São Paulo, 03 de novembro 2010.

Machado de Assis, leitor (autor) da Revista do Instituto Histórico e Geográfico Brasileiro. In: JOBIM, José Luís (Org.). A biblioteca de Machado de Assis. Rio de Janeiro: ABL; Topbooks, 2001. p. 315-334.

VIANNA, Glória. Revendo a biblioteca de Machado de Assis. In: JOBIM, José Luís (Org.). A biblioteca de Machado de Assis. Rio de Janeiro: ABL; Topbooks, 2001. p. 99274.

www.academia.org.br

Luciana Antonini Schoeps é doutoranda em Letras (Estudos Linguísticos, Literários e Tradutológicos em Francês) na Universidade de São Paulo. Mestre pela mesma instituição, defendeu a dissertação "Bibliotecas fantásticas em chamas: Machado de Assis e Gustave Flaubert", financiada pela FAPESP. Publicou na Revista Manuscrítica $\mathrm{n}^{\circ} 20$ o artigo "A ficcionalização do literário nas bibliotecas fantásticas de Gustave Flaubert e Machado de Assis"; e, na Revista Criação \& Crítica no 2, o artigo "À roda dos delírios de morte de Machado e Flaubert: Memórias póstumas de Brás Cubas e Un cour simple". E-mail: lucianaschoeps@yahoo.com.br

Recebido: 15.03.2013

Aprovado: 19.06.2013 